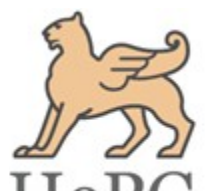

\title{
Symphyodon erraticus (Symphyodontaceae): an addition to the moss flora of the Western Ghats
}

\author{
R. Sreebha, K. C. Kariyappa and A. E. D. Daniels* \\ Bryology Laboratory, Department of Botany \& Research Centre, Scott Christian College, Nagercoil - 629 003, Tamil Nadu, India
}

Article history

Received: 14 August 2015

Accepted: 10 September 2015

Published online: 1 October 2015

(c) Sreebha et al. (2015)

Editors

Afroz Alam

Dipjyoti Chakraborty

Publisher

Horizon e-Publishing Group

Corresponding Author

A. E. D. Daniels

区 dulipdaniels@yahoo.co.uk

\begin{abstract}
The moss Symphyodon erraticus has been discovered from the Western Ghats and is an addition to the moss flora of the W. Ghats. A brief description with illustrations and a colour plate is provided.
\end{abstract}

Keywords

Moss; Symphyodon erraticus; Western Ghats

Sreebha, R., Kariyappa, K. C. and Daniels, A. E. D. 2015. Symphyodon erraticus (Symphyodontaceae): an addition to the moss flora of the Western Ghats. Plant Science Today 2(4): 129-131. http://dx.doi.org/10.14719/pst.2015.2.4.140

\section{Introduction}

Mitten (1859), described a new species of moss Stereodon erraticus based on specimens from Southeast Asia. Jaeger (1878) placed it under Symphyodon Mont. and made a new combination Symphyodon erraticus. Since then, this species has been listed only in checklists (Bruehl, 1931; O'Shea, 2002; Lal, 2005). However, Gangulee provided a description based on Kurz's collection from Tongloo (now Tonglu) in Darjeeling, Eastern Himalaya in 1868 between September and November (vide Gangulee 1969, Vol. 1(1): vi) and also $\mathrm{He}$ (2000) in his revision provided descriptions based on specimens collected by the $19^{\text {th }}$ century European colonizers. Recently, Sahu and Asthana (2014) have reported this species from the Western Himalaya. Therefore, the present report is an addition of this species to the moss flora of the Western Ghats since all earlier Indian reports are from the Himalaya. A brief description with illustrations and a colour plate is provided. Specimens are housed at SCCN.
Symphyodon erraticus (Mitt.) A. Jaeger, Ber. Thätigk. St. Gallischen Naturwiss. Ges.: 296. 1878.

Gangulee, Moss. E. India 2(6): 1517, f. 759. 1977; He, Bryologist 103: 75. 2000. Stereodon erraticus Mitt., J. Proc. Linn. Soc., Bot. 2(Suppl.): 111. 1859.

Plants robust, $2-5 \mathrm{~cm}$ long, reddish (Figs. 1 \& 2). Stems creeping, ca $0.14 \times 0.09 \mathrm{~mm}$ in cross section, ovate, without a central strand; cortex 1-4-layered; cells 4-8 $\times 2-4 \mathrm{~mm}$, thick-walled; medullary ones 8-24 × 8-16 $\mathrm{mm}$, thin-walled; branches $0.4-1.5 \mathrm{~cm}$, erect, 2- or 3pinnate. Leaves many-rowed, patent, $0.8-1 \times 0.28-0.45$ $\mathrm{mm}$, ovate-lanceolate, concave, entire at margin below, recurved above, toothed at apex; cells linear elongate, sometimes with raised, papillate apices; apical ones 12 $28 \times 4-6 \mu \mathrm{m}$; median ones 40-60 × 4-6 $\mu \mathrm{m}$; basal ones 28-44 × 4-8 $\mu \mathrm{m}$; those at extreme base $12-28 \times 8-10 \mu \mathrm{m}$, quadrate; costa short, double, ca $1 / 3$ as long as leaf. Sporophyte not seen.

Habitat: Rupicolous in evergreen forests and corticolous on Cullenia exarillata Robyns (Bombacaceae), an endemic, keystone lofty tree in evergreen forests, 1040 - $1868 \mathrm{~m}$. 


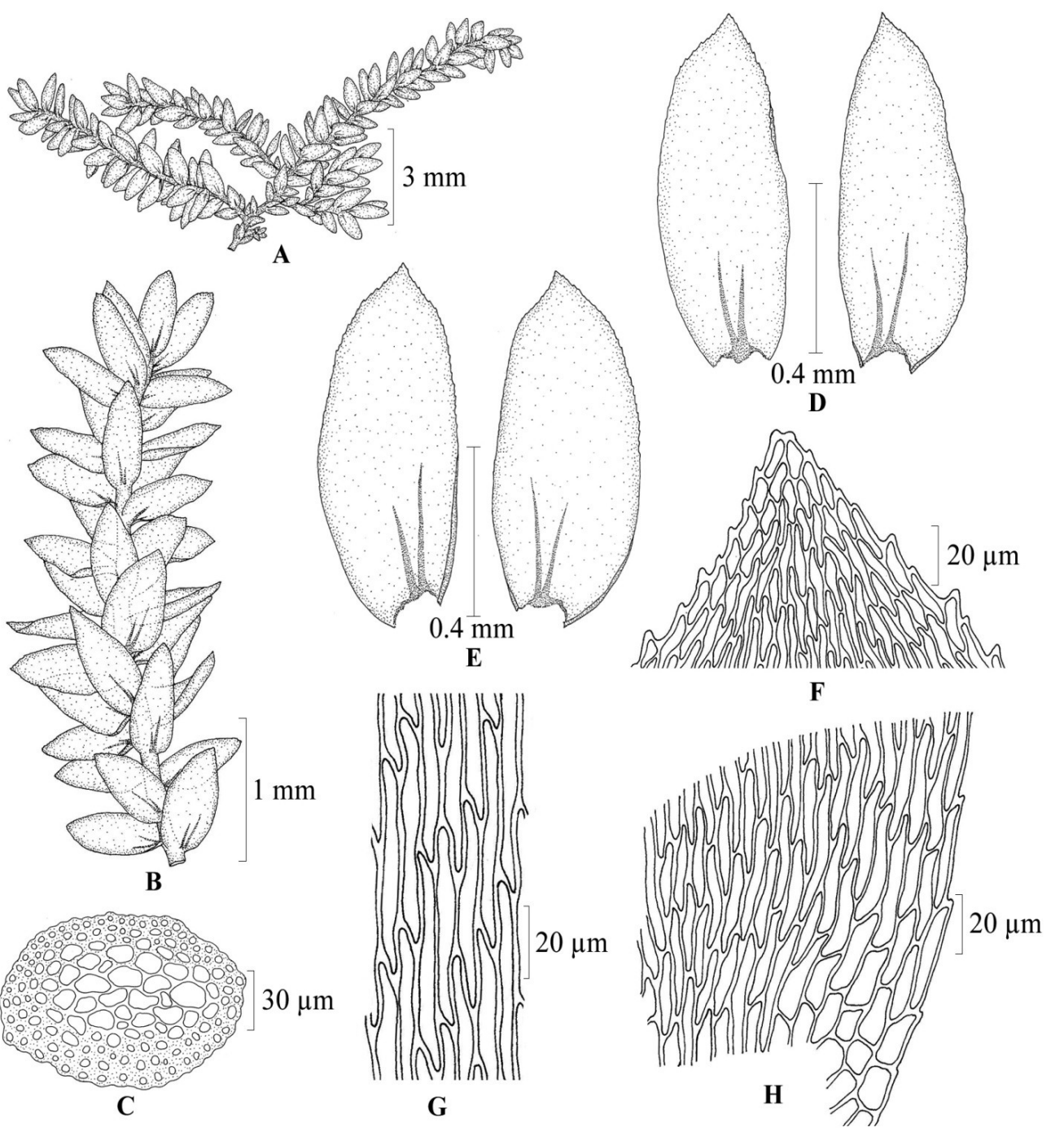

Fig. 1. Symphyodon erraticus (Mitt.) A. Jaeger, from Western Ghats (Daniels \& Kariyappa 9254 p.p.): (A) Plant, (B) portion of plant, (C) cross section of stem, (D) stem leaves, (E) Branch leaves, (F) leaf apical cells, (G) leaf median cells, and (H) leaf basal cells

Distr.: Bhutan, Indonesia, Myanmar, Nepal, Thailand, Sri Lanka and India: Eastern Himalaya and Western Ghats of Tamil Nadu (Tirunelveli), rare.

Specimens examined: Western Ghats: Tamil Nadu, Tirunelveli Dist., Agasthyamalai Biosphere Reserve, Agasthyamalai peak, ca $1868 \mathrm{~m}, 19.4 .2010$, K.C. Kariyappa 3723 p.p.; Druripparai, ca 1300 m, 20.4.2010, K.C. Kariyappa 3746 p.p.; Coimbatore Dist., Anamalai Tiger Reserve, Anamalais, Valparai, ca 1040 m, 19.2.2013, A.E.D. Daniels \& K.C. Kariyappa 9254 p.p., 9255 p.p.

\section{Discussion}

Symphyodon erraticus is so far known only from South and Southeast Asia. In India, it is known from the Himalaya and presently from the Western Ghats. With Sri Lanka and the Western Ghats in Peninsular India generally treated as a single biodiversity hotspot (Gunawardene et al., 2007), this species appears to have a very restricted distribution. Further, its occurrence in the evergreen forests of the Western Ghats stresses the need for conservation of evergreen forests which generally harbour delicate mosses such as $S$. erraticus which are sensitive to loss of humidity resulting from the opening up of forest canopy.

\section{Acknowledgements}

We thank the Tamil Nadu State Forest Department for permission to explore the study area and help in the field. AEDD thanks the Department of Science and Technology (DST), New Delhi, for financial assistance, A.K. Asthana (LWG), for help with literature and the Principal, Scott Christian College, for facilities.

\section{References}

Bruehl, P. 1931. A census of Indian mosses with analytical keys to the genera. Rec Bot Surv India 13(1): 1-135; 13(2), 1-152.

Gangulee, H. C. 1974-1977. Mosses of Eastern India and adjacent regions. 2 (Fasc. 4-6). (Calcutta, India) 831-1546 pp.

Gunawardene, N. R., A. E. D. Daniels, I. A. U. N. Gunatilleke,C. V. S. Gunatilleke, P.V. Karunakaran, K. G. Nayak, S. Prasad, P. Puyravaud, B. R. Ramesh, K. A., Subramanian, and G. Vasanthy. 2007. A brief overview of the Western Ghats-Sri 

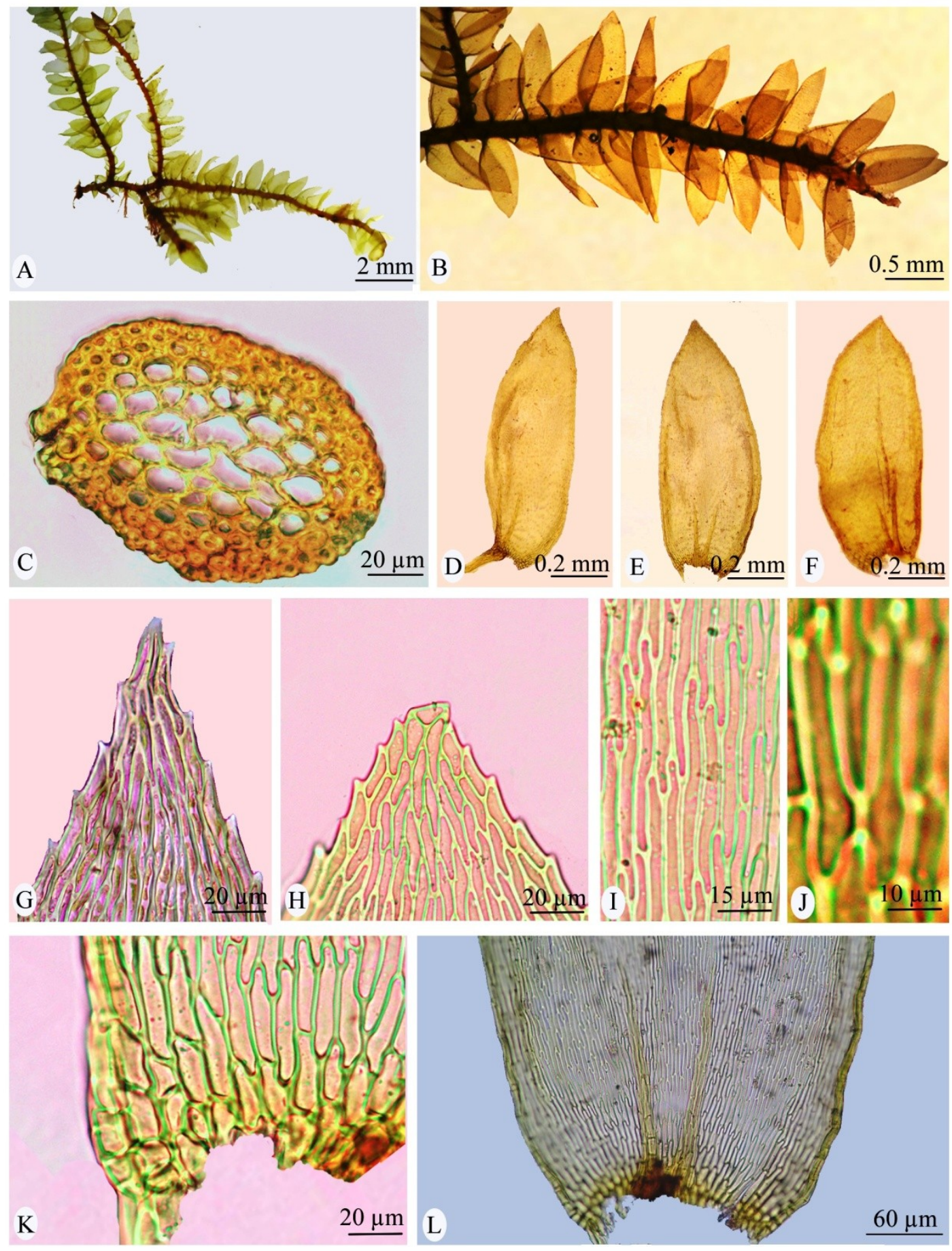

Fig. 2. Symphyodon erraticus (Mitt.) A. Jaeger, from Western Ghats (Daniels \& Kariyappa 9254 p.p.): (A) Plant, (B) portion of plant, (C) cross section of stem, (D) stem leaf, (E-F) Branch leaves, (G) stem leaf apex, (H) branch leaf apex, (I) leaf median cells, (J) leaf basal cells with papillae, (K) leaf extreme basal cells, (L) lower half of leaf with costa

Lanka biodiversity hotspot. Curr Sci 93: 15671572.

He, S. 2000. A taxonomic revision of Symphyodon (Musci: Symphyodontaceae). Bryologist 103: 5281.

Jaeger, A. 1878. Cylindrotheciaceae. In: Jaeger A. and Sauerbeck F. Adumbratio Flora Muscorum et Conspectus Systematis; Musci. Ber. Thätigk. St. Gallischen Naturwiss. Ges. (Switzerland: St. Gallen) p. 271-299.

Lal, J. 2005. A checklist of Indian mosses. Bishen Singh Mahendra Pal Singh, Dehra Dun, India. 164pp.
Mitten, W. 1859. Musci Indiae Orientalis. J Proc Linn Soc Bot 1(Suppl.): 1-171.

O'Shea, B. J. 2002. Checklist of the mosses of Sri Lanka. J Hattori Bot Lab 92: 125-164.

Sahu, V. and A. K. Asthana 2014. Two Mosses New to West Himalayan Bryoflora. Proc Natl Acad Sci India Sect B Biol Sci 84: 805-810.

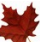

